\title{
Using Colchicine to Create Poinsettia (Euphorbia pulcherrima $\times$ Euphorbia cornastra) Mutants with Various Morphological Traits
}

\author{
I-Chun Pan, Ya-Fen Lu, Pei-Jung Wen, and Yen-Ming Chen \\ Department of Horticulture, National Chung Hsing University, 145 Xingda \\ Road, South District, Taichung City 402, Taiwan, Republic of China
}

Additional index words. colchicine, mutation, plant characteristic, poinsettia, polyploidy

\begin{abstract}
Commercially available novel cultivars of poinsettia, obtained through interspecific hybridization, were subject to colchicine-based mutagenesis to recover their fertility, enabling subsequent breeding. Mutagenic treatment was conducted at different concentrations of colchicine with either lanolin or cotton serving as the matrix. The results indicated that 1 day was the optimal duration of colchicine treatment and that suitable colchicine concentration varied by cultivar. Moreover, one-time treatment gave higher rates of both polyploidy and morphological mutant production than two-times treatment. Specifically, the poinsettia cultivars Dulce Rosa $\left(5 \mathrm{mg} \cdot \mathrm{g}^{-1}\right.$ colchicine with lanolin; $10 \mathrm{mg} \cdot \mathrm{mL}^{-1}$ colchicine with cotton) and Princettia-Hot Pink (15 mg.g ${ }^{-1}$ colchicine with lanolin; $10 \mathrm{mg} \cdot \mathrm{mL}^{-1}$ colchicine with cotton) yielded relatively high polyploidy production efficiency and morphological mutation rate. Consequently, a total of three polyploidy mutants of 'Dulce Rosa' and 19 polyploidy mutants of 'Princettia-Hot Pink' were obtained. Both cultivars had mutants with recovered fertility, with pollen germination rate of up to $\mathbf{2 7 . 5 \%}$. Moreover, unexpected non-polyploidy mutants with various morphological trait variations were also obtained.
\end{abstract}

Poinsettia (Euphorbia pulcherrima) belongs to the spurge family (Euphorbiaceae). Its place of origin is southern Mexico to Northern Guatemala. This small deciduous tree can reach more than $3 \mathrm{~m}$ high and grows bright red bracts in winter (Ecke et al., 2004). Most pre-1960 commercial cultivars of poinsettia were obtained from the somatic mutation of Oak Leaf (Datta, 1991). After the cultivar with red bracts was obtained by cross breeding with expanded germplasm sources, artificial mutation is induced to produce a series of cultivars with pink, marble, and yellowish-white colors. Ecke et al. (1990) investigated commercially available poinsettia cultivars, finding that more than $80 \%$ of all cultivars were obtained through mutation breeding. For example, through exposing 'Peterstar-Red' to gamma rays, six cultivars with other bract colors were obtained (Ecke et al., 2004).

The aforementioned breeding process shows that before the 21 st century, new cultivars of poinsettia were primarily obtained through intraspecific hybridization or bud spontaneous mutation. However, contin-

\footnotetext{
Received for publication 17 Apr. 2019. Accepted for publication 10 July 2019 .

Supported by grants from the Ministry of Science and Technology (no. MOST 107-2313-B-005-015-MY3 and MOST 106-2313-B-005-028-) and the Council of Agriculture, Agriculture and Food Agency (107AS-7.4.1-FD-Z1), Taiwan.

Y.-M.C. is the corresponding author. E-mail: chenym@dragon.nchu.edu.tw.
}

ual variety improvement has gradually reduced the morphological differences between cultivars. To create novel cultivars or improve resistance against pests and diseases, breeding experts worldwide have expanded the base of germplasm sources and attempted to hybridize poinsettia with its relatives in Euphorbia (Ecke et al., 2004). The American Paul Ecke Ranch released an interspecies hybrid of poinsettia with Euphorbia cornastra, a species native to Mexico. This novel cultivar was named Eckespoint 'Dulce Rosa'. The bracts of 'Dulce Rosa' have a unique florescent pink color never previously seen in poinsettia; furthermore, through shading adjustment to control the photoperiod, this cultivar can be made to flower in spring or summer to satisfy market needs for Easter and Mother's Day (Ecke et al., 2004). In addition, the Japanese Suntory Group used the same hybridization combination (E. pulcherrima $\times E$. cornastra) to obtain 'Princettia', a superior cultivar with florescent dark pink bracts and notched leaf margin. After mutation breeding, six colors in this series were released into the market, including white, light pink, and hot pink cultivars.

Because of the genomic difference between the parental species used for producing 'Dulce Rosa' and 'Princettia-Hot Pink', these two cultivars show sterility and their flowers cannot develop normal anthers and female reproductive organs. Therefore, colchicine has been used to produce amphidiploid to recover fertility in these cultivars, enabling subsequent breeding experiments. The breeding methods of these novel poinsettia cultivars are described only in plant patent statements, which do not state the optimal concentration and method for inducing polyploidy mutation. Therefore, in this study, we aimed to determine the optimal concentration of colchicine for inducing mutation in these novel poinsettia cultivars and to evaluate the polyploidy mutagenic rate, pollen germination ability, and changes in plant traits.

\section{Materials and Methods}

Propagating and managing plant materials. All parent plants for the test were planted in a planting bed in the rainproof shed of the Horticulture Center in National Chung Hsing University, Taiwan. Tip cuttings with 5 to 7 nodes were harvested in July 2013 for cutting propagation. After the bases of the tips were dipped into $1 \mathrm{mg} \cdot \mathrm{g}^{-1}$ of indole-3butyric acid (Sigma-Aldrich, St Louis, MO) talcum powder, the tips were planted in foam cubes (Pioneer U.N. Co. Ltd., Taichung City, Taiwan) and the foam was placed in a mist bed for rooting. After the cuttings had rooted, they were removed from the moist environment and planted in $7.62-\mathrm{cm}$ plastic pots for acclimation. The cultivation medium used was a mixture of commercial peatmoss and medium BVB 7H (7H PO441389; Bas van Buuren B.V., De Lier, The Netherlands). The top of these plants were pinched 2 weeks after the cultivation, and moved to different plastic pots (size: $10.16 \mathrm{~cm}$ and $12.7 \mathrm{~cm}$ ) depending on their status of growth. During the cultivation period, $1 \mathrm{~g} \cdot \mathrm{L}^{-1}$ Jack's water soluble fertilizer $20 \mathrm{~N}-8.8 \mathrm{P}-16.6 \mathrm{~K}$ (ScottsSierra Horticultural Products Co., Marysville, $\mathrm{OH}$ ) was applied to the plants three times each week. In addition, $0.2 \mathrm{~g} \cdot \mathrm{L}^{-1}$ FeEDTA (Dissolvine E-Fe-13 Chelated Iron Powder 13\%; AkzoNobel, Amsterdam, The Netherlands), $0.2 \mathrm{~g} \cdot \mathrm{L}^{-1} \mathrm{MgSO} 4$ (Bittersalz; K+S KALI GmbH, 34111 Kassel, Germany), and $0.2 \mathrm{~g} \cdot \mathrm{L}^{-1} \mathrm{Na}_{2} \mathrm{MoO}_{4} \cdot 2 \mathrm{H}_{2} \mathrm{O}$ were applied as appropriate, and pest control was performed regularly.

Administering colchicine treatment to poinsettia. The interspecific hybrid cultivars of poinsettia Dulce Rosa and Princettia-Hot Pink were transplanted into $5.08-\mathrm{cm}$ plastic pots after their cuttings had rooted. After 4 weeks of cultivation, lanolin paste containing colchicine at the concentrations of $5,10,15$, or $20 \mathrm{mg} \cdot \mathrm{g}^{-1}$ was used for the treatment. The colchicine-containing lanolin was applied to selected axillary buds at $1200 \mathrm{HR}$ on Day 1 as the first treatment, and again to the same axillary buds at the same time $7 \mathrm{~d}$ later for the second treatment. As an alternative method, a cotton ball (diameter: $5 \mathrm{~mm}$ ) was placed on each axillary bud and $2 \mathrm{~mL}$ of colchicine solution with concentration of $5,10,15$, or 20 $\mathrm{mg} \cdot \mathrm{mL}^{-1}$ was applied to each cotton ball at $1200 \mathrm{HR}$ and $2400 \mathrm{HR}$. For consecutive treatment, the same colchicine concentration also was applied the next day at the same times. The terminal buds with about three internodes were removed from the test plants after completion of the colchicine treatment. 
Three plants, each with $\approx 20 \mathrm{~cm}$ height and at least 15 axillary buds, located at $\approx 10$ internodes from the shoot tip were treated. In total, 30 axillary buds were used. Eight weeks after the colchicine treatment, the survival rate of these colchicine-treated axillary buds was recorded and flow cytometric analysis was used to assess the relative DNA content of the surviving buds. These buds were then subjected to cutting propagation and cultivation using the same method mentioned previously. The surviving mutants were continuously cultivated in a natural short day for the convenience of subsequent investigation on plant morphology.

Investigating the traits of colchicineinduced mutants. The mutants obtained in the test and control plants were cultivated in a natural environment during short daylength period to investigate their cyathium pattern. When the bracts were completely colored, the primacy cyathium diameter and bract size were measured. Bract color was compared with the RHS color chart (the Royal Horticultural Society, London, UK) and recorded using color codes (i.e., color group number). In addition, the mutants' morphological traits were documented, such as leaf shape, bract shape, and recovery of normal floral organ.

Assessing the pollen grain size and pollen germination rate of colchicine-induced mutants. The mutants with a cyathium involucre capable of developing anthers and releasing pollen normally were selected for investigation. On a sunny day, fresh pollen from dehisced anthers on that day was collected and cultured on a microscope slide using B\&K medium (Brewbaker and Kwack, 1963), which contained $20 \%$ sucrose. The pollen specimens were cultured in a dark environment at $20{ }^{\circ} \mathrm{C}$ for $10 \mathrm{~h}$. An optical microscope (ZEIZZ HBO 50/AC; Zeiss Axiolab, Oberkochen, Germany) equipped with a digital camera (Prog Res CF scan; JENOPTIK, Jena, Germany) was used to observe the specimens. The germination rate and pollen size were calculated. When the length of the pollen tube was two times the pollen grain diameter, the pollen was defined as germinated. Image analysis software Prog Res Capture Pro 2.7 was adopted to measure the pollen grain diameter. For each treatment of the test, 200 pollen grains were investigated with three replicates each.

Evaluating the relative DNA content of colchicine-induced mutants. The relative DNA content of the surviving mutants was compared with that of the donor plants. After preliminary confirmation of relative DNA content, Trifolium repens was first selected as an internal standard for later flow cytometric analysis of the donor cultivar and colchicine-induced mutants. A thin slice of $\approx 0.25 \mathrm{~cm}^{2}$ was collected from each plant and added with $400 \mu \mathrm{L}$ of Solution A (Nuciel Extraction Buffer; Partec GmbH, Münster, Germany). The specimens were chopped evenly using a shaving blade. Subsequently, $1600 \mu \mathrm{L}$ of Solution B (Staining Buffer; Partec $\mathrm{GmbH}$ ) was added to the previous solution containing leaf residue and mixed for 1 min to achieve evenness. A nylon net of $30-\mu \mathrm{m}$ mesh was used to filter impurities and plant residue to obtain a sample solution with plant nuclei for analysis. A flow cytometry device (CyFlow Cube 6, Ploidy Analyzer; Partec $\mathrm{GmbH}$ ) was used to analyze the relative DNA content of the specimens (Chen and Mii, 2012a, 2012b).

Statistical analysis. A completely randomized design was adopted in this study. The data for all the experiments were analyzed by analysis of variation. Means were separated using the least significant difference at $P \leq 0.05$.

\section{Results}

Effect of colchicine treatment on the mutagenesis of 'Dulce Rosa'. In the colchicine treatment, most axillary buds were withering or dead 2 weeks after the treatment, whereas the few surviving buds grew slowly. The survival rate, polyploidy mutagenic rate, and plant morphological mutation rate of the axillary buds of 'Dulce Rosa' were investigated 8 weeks after their mutagenic treatment (Table 1). Significantly high survival rate was obtained when lanolin served as the matrix of colchicine was administered to the axillary buds twice at the concentration of $5 \mathrm{mg} \cdot \mathrm{g}^{-1}$. All axillary buds died with $20 \mathrm{mg} \cdot \mathrm{g}^{-1}$ colchicine, regardless of treatment frequency. Polyploidy was detected in only one of the four surviving buds that were subjected to one-time treatment at a concentration of $5 \mathrm{mg} \cdot \mathrm{g}^{-1}$. The maximum number of non-polyploidy mutants with morphological variance were obtained from the treatment with $5 \mathrm{mg} \cdot \mathrm{g}^{-1}$ colchicine.

By contrast, when cotton was used as the matrix of colchicine, the maximum survival rate was observed among the buds receiving 1-d treatment at $5 \mathrm{mg} \cdot \mathrm{mL}^{-1}$. However, the bud survival rate was still high even when colchicine concentration was increased to $20 \mathrm{mg} \cdot \mathrm{mL}^{-1}$. When the treatment frequency was increased to $2 \mathrm{~d}$, the highest bud survival rate was obtained at $5 \mathrm{mg} \cdot \mathrm{mL}^{-1}$ colchicine concentration. The bud survival rates were lower at high concentrations. The polyploidy of all surviving buds was assessed using flow cytometry. Only two polyploidy mutants were induced from the buds treated on $1 \mathrm{~d}$ with $10 \mathrm{mg} \cdot \mathrm{mL}^{-1}$ colchicine.

Effect of colchicine treatment on 'Princettia-Hot Pink'. Table 2 displays the results of treating 'Princettia-Hot Pink' with colchicine. When mutagen-containing lanolin was applied to the buds once, the highest bud survival rate of one-time treatment was obtained at a colchicine concentration of 5 $\mathrm{mg} \cdot \mathrm{g}^{-1}$, and the lowest bud survival rate was recorded at $10 \mathrm{mg} \cdot \mathrm{g}^{-1}$. All axillary buds subjected to two treatments with mutagencontaining lanolin gave lower bud survival rate than that with one treatment. When two treatments with colchicine-containing lanolin were administered, the highest bud survival rate was obtained when the buds were treated with $15 \mathrm{mg} \cdot \mathrm{g}^{-1}$ colchicine concentration. This study consequently showed that the highest polyploidy mutagenic rate was ob- tained when colchicine treatment was administered once at $15 \mathrm{mg} \cdot \mathrm{g}^{-1}$.

When a cotton ball was used as the attachment matrix for colchicine, the highest bud survival rate was obtained when colchicine solution at $15 \mathrm{mg} \cdot \mathrm{mL}^{-1}$ was administered as 2-d treatment. Only one polyploid mutant was induced from the buds that received 2-d colchicine treatments at 5 $\mathrm{mg} \cdot \mathrm{mL}^{-1}$, and another polyploidy was induced from those with 1-d colchicine treatment at $10 \mathrm{mg} \cdot \mathrm{mL}^{-1}$.

Traits of colchicine-induced mutants. Our investigation of all 'Dulce Rosa' mutants obtained through colchicine treatment demonstrated that morphological variations were found among them (Tables 1 and 3, Fig. 1). Compared with the morphological traits of 'Dulce Rosa', the bract colors of the two mutants D-M1 and D-M2 were darker than that of the donor plant. In addition, the bract width of all mutants were greater, leading to relatively elliptical bract shapes (the bract-leaf blade ratio was lower). In the colchicine treatments on 'Princettia-Hot Pink', numerous mutants with morphological variations were obtained (Tables 2 and 4, Fig. 2). Most of them had greater single cyathium diameter than the donor plant. Compared with those of 'Princettia-Hot Pink', the bracts of some mutants were darker in color. Both bract length and width of most mutants were larger than the original cultivar, leading to relatively elliptical bract shapes (lower bract-leaf blade ratio).

Although 'Dulce Rosa' had a structure with abnormally developed stamens, no pollen was contained in the anthers (Fig. 3A). Mutant D-M1 had a normally developed male floral organ, with normal filaments and dehisced anthers capable of releasing pollen (Fig. 3B). Some of the pollen ( $8 \%)$ successfully germinated on B\&K medium containing 20\% sucrose for $10 \mathrm{~h}$ (Fig. 3C, Table 3). Flow cytometric analysis revealed that D-M1 had a tetraploid level of DNA content (Fig. 3D, Table 3). Flow cytometric analysis also revealed that D-M2 mutants had unexpectedly less DNA content than the original cultivar. Although two other mutants (D-M3 to D-M9) had identical relative DNA content to 'Dulce Rosa', they showed morphological differences from the donor plant. In addition, 'Princettia-Hot Pink' had anthers that could protrude from the involucre, they had only a few stamens of normal development (Fig. 3E). Moreover, the pollen produced in these anthers could not germinate after $10 \mathrm{~h}$ of culture on the same culture medium as used for 'Dulce Rosa' (Fig. 3G, Table 4). In contrast, some mutants obtained through colchicine treatment showed a higher number of stamens with pollen protruding from the involucre (Fig. 3F). The pollen produced in these mutants was larger than that of the original cultivar and could germinate well in the pollen culture medium (Fig. 3H). Especially, three mutants with tetraploid-level DNA contents (P-M8, P-M13, P-M14) showed relatively higher pollen germination rates than $13 \%$, and the 
Table 1. Effect of different colchicine treatment methods and concentrations on the mutagenic efficiency of poinsettia 'Dulce Rosa'.

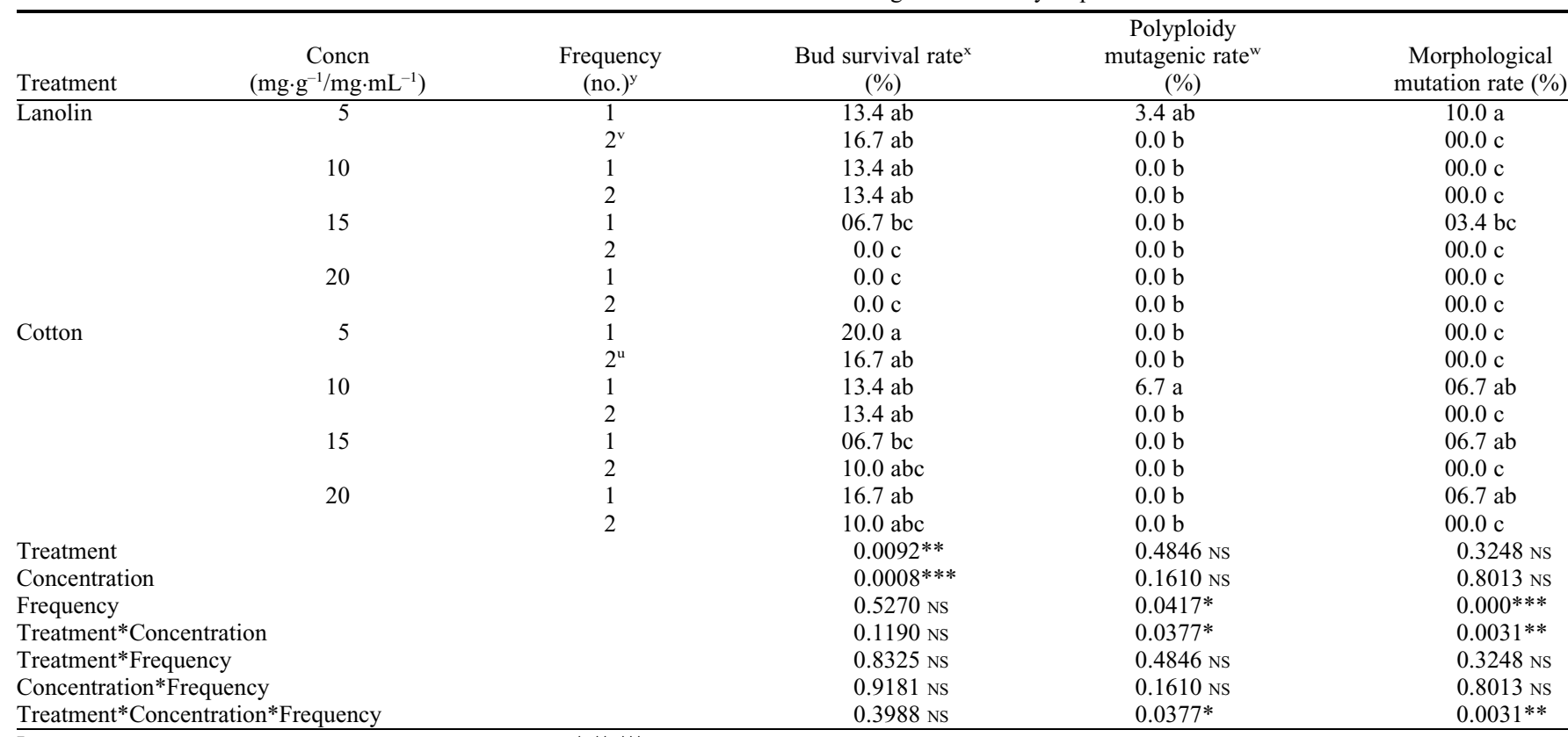

${ }^{\mathrm{z}}$ Significance was determined by analysis of variance; ${ }^{\mathrm{NS},}{ }^{*},{ }^{* *},{ }^{* * *}$ Nonsignificant or significant at $P \leq 0.05,0.01$, or 0.001 , respectively. Means within a column followed by the different letters are significantly different according to least significant difference test; $P \leq 0.05$ indicates significant difference.

${ }^{\mathrm{y}}$ Total of 30 axillary buds were used for each treatment.

${ }^{\mathrm{x}}$ (No. of surviving axillary buds/No. of axillary buds treated) $\times 100$; the survival rate was investigated 8 weeks after the mutagenic treatment.

${ }^{\mathrm{w}}$ (Number of polyploidies/No. of axillary buds treated) $\times 100$. Mutants with considerably different relative DNA content from that of the control group 8 weeks after the treatments were categorized as polyploidies.

${ }^{\mathrm{v}}$ Twice treatment with lanolin: $7 \mathrm{~d}$ after the first mutagen treatment, the same buds received second treatment with lanolin containing the same concentration of colchicine.

${ }^{\mathrm{u}}$ Two-day treatment with cotton: the same buds received a second treatment with cotton containing the same concentration of colchicine on the next day.

Table 2. Effects of different treatment methods and colchicine concentrations on the mutagenic efficiency of poinsettia 'Princettia-Hot Pink' ${ }^{\mathrm{z}}$

\begin{tabular}{|c|c|c|c|c|c|}
\hline Treatment & Concn $\left(\mathrm{mg} \cdot \mathrm{g}^{-1} / \mathrm{mg} \cdot \mathrm{mL}^{-1}\right)$ & $\begin{array}{l}\text { Frequency } \\
\text { (no.) })^{y}\end{array}$ & $\begin{array}{c}\text { Bud survival rate } \\
(\%)\end{array}$ & $\begin{array}{c}\text { Polyploidy } \\
\text { mutagenic rate } \\
(\%)\end{array}$ & $\begin{array}{l}\text { Morphological } \\
\text { mutation rate } \\
(\%)\end{array}$ \\
\hline \multirow[t]{5}{*}{ Lanolin } & 5 & 1 & $60.0 \mathrm{a}$ & $16.7 \mathrm{~b}$ & $26.7 \mathrm{a}$ \\
\hline & & $2^{\mathrm{v}}$ & $13.4 \mathrm{ef}$ & $00.0 \mathrm{c}$ & $03.4 \mathrm{~cd}$ \\
\hline & & 2 & $16.7 \mathrm{ef}$ & $00.0 \mathrm{c}$ & $06.7 \mathrm{~cd}$ \\
\hline & 15 & 1 & $53.3 \mathrm{ab}$ & $30.0 \mathrm{a}$ & $30.0 \mathrm{a}$ \\
\hline & & 2 & $26.7 \mathrm{cdef}$ & $00.0 \mathrm{c}$ & $06.7 \mathrm{~cd}$ \\
\hline \multirow[t]{7}{*}{ Cotton } & 5 & 1 & $13.4 \mathrm{ed}$ & $00.0 \mathrm{c}$ & $10.0 \mathrm{bcd}$ \\
\hline & & $2^{u}$ & $23.3 \mathrm{def}$ & $03.4 \mathrm{c}$ & $10.0 \mathrm{bcd}$ \\
\hline & 10 & 1 & $26.7 \mathrm{cdef}$ & $03.4 \mathrm{c}$ & $23.3 \mathrm{ab}$ \\
\hline & & 2 & $40.0 \mathrm{abcd}$ & $00.0 \mathrm{c}$ & $10.0 \mathrm{bcd}$ \\
\hline & 15 & 1 & $20.0 \mathrm{ef}$ & $00.0 \mathrm{c}$ & $00.0 \mathrm{~d}$ \\
\hline & & 2 & $46.7 \mathrm{abc}$ & $00.0 \mathrm{c}$ & $16.7 \mathrm{abc}$ \\
\hline & 20 & 1 & $13.4 \mathrm{ef}$ & $00.0 \mathrm{c}$ & $06.7 \mathrm{~cd}$ \\
\hline \multicolumn{3}{|c|}{ Treatment*Frequency } & $0.000 * * *$ & $0.000 * * *$ & $0.0032 * *$ \\
\hline \multicolumn{3}{|c|}{ Concentration*Frequency } & $0.2415 \mathrm{NS}$ & $0.0003 * * *$ & $0.3784 \mathrm{NS}$ \\
\hline \multicolumn{3}{|c|}{ Treatment*Concentration*Frequency } & $0.7007 \mathrm{NS}$ & $0.0001 * * *$ & $0.0078 * *$ \\
\hline
\end{tabular}

${ }^{\mathrm{Z}}$ Significance was determined by analysis of variance; ${ }^{\mathrm{NS},},{ }^{* * *}, * * *$ Nonsignificant or significant at $P \leq 0.05,0.01$, or 0.001 , respectively. Means within a column followed by the different letters are significant different according to least significant difference test; $P \leq 0.05$ indicates significant difference.

${ }^{\mathrm{y}}$ Total of 30 axillary buds were used for each treatment.

${ }^{\mathrm{x}}$ (No. of surviving axillary buds/No. of axillary buds treated; the survival rate was investigated 8 weeks after the mutagenic treatment.

${ }^{\mathrm{w}}$ (Number of polyploidies/No. of axillary buds treated) $\times 100$. Mutants with considerably different relative DNA content from that of the control group 8 weeks after the treatments were categorized as polyploidies.

${ }^{\mathrm{v}}$ Twice treatment with lanolin: $7 \mathrm{~d}$ after the first mutagen treatment, the same buds received a second treatment with lanolin containing the same concentrations of colchicine.

${ }^{\mathrm{u}}$ Two-day treatment with cotton: the same buds received a second treatment with cotton containing the same concentration of colchicine on next day. 
Table 3. Morphological traits of colchicine-induced mutants of poinsettia 'Dulce Rosa'.

\begin{tabular}{|c|c|c|c|c|c|c|c|c|}
\hline $\begin{array}{l}\text { Mutant } \\
\text { line }\end{array}$ & $\begin{array}{c}\text { Single } \\
\text { cyathium } \\
\text { diam }(\mathrm{cm})\end{array}$ & $\begin{array}{l}\text { Bract } \\
\text { length } \\
(\mathrm{cm})\end{array}$ & $\begin{array}{l}\text { Bract } \\
\text { width } \\
(\mathrm{cm})\end{array}$ & $\begin{array}{c}\text { Bract- } \\
\text { leaf } \\
\text { blade ratio }\end{array}$ & $\begin{array}{l}\text { Bract } \\
\text { color } \\
\text { (RHS) }\end{array}$ & $\begin{array}{c}\text { Pollen } \\
\text { grain } \\
\text { diam }(\mu \mathrm{m})\end{array}$ & $\begin{array}{c}\text { Pollen } \\
\text { germination } \\
\text { rate }^{\mathrm{y}}(\%)\end{array}$ & $\begin{array}{c}\text { Relative } \\
\text { DNA } \\
\text { content (units) }\end{array}$ \\
\hline Control $^{x}$ & 13.2 & $7.6 \mathrm{a}$ & $2.5 \mathrm{e}$ & $2.4 \mathrm{a}$ & $57 \mathrm{D}$ & $-{ }^{w}$ & - & 2.0 \\
\hline D-M1 & 12.7 & $6.2 \mathrm{ef}$ & $2.8 \mathrm{~d}$ & $1.9 \mathrm{~b}$ & $57 \mathrm{~A}$ & 49.8 & 8 & 3.96 \\
\hline D-M2 & 17.3 & $5.3 \mathrm{~g}$ & $4.2 \mathrm{a}$ & $1.9 \mathrm{bc}$ & $57 \mathrm{~B}$ & - & - & 1.69 \\
\hline D-M3 & 16.3 & $7.8 \mathrm{a}$ & $3.6 \mathrm{~b}$ & $1.9 \mathrm{~b}$ & $66 \mathrm{~B}$ & - & - & 2.0 \\
\hline D-M4 & 15.9 & $6.8 \mathrm{~cd}$ & $3.1 \mathrm{c}$ & $2.2 \mathrm{a}$ & $57 \mathrm{~B}$ & - & - & 2.0 \\
\hline D-M5 & 18.0 & $6.7 \mathrm{~d}$ & $3.1 \mathrm{c}$ & $2.2 \mathrm{a}$ & $67 \mathrm{C}$ & - & - & 2.0 \\
\hline D-M6 & 19.0 & $7.0 \mathrm{bc}$ & $3.8 \mathrm{~b}$ & $1.6 \mathrm{c}$ & $66 \mathrm{~A}$ & - & - & 2.14 \\
\hline D-M7 & 15.9 & $6.3 \mathrm{e}$ & $2.7 \mathrm{de}$ & $2.2 \mathrm{a}$ & $57 \mathrm{~B}$ & - & - & 2.0 \\
\hline D-M8 & 17.7 & $6.0 \mathrm{f}$ & $3.4 \mathrm{c}$ & $2.3 \mathrm{a}$ & $57 \mathrm{C}$ & - & - & 2.16 \\
\hline D-M9 & 17.4 & $7.2 \mathrm{~b}$ & $3.4 \mathrm{c}$ & $2.2 \mathrm{a}$ & $57 \mathrm{C}$ & - & - & 2.0 \\
\hline
\end{tabular}

${ }^{\mathrm{z}}$ Means within a column followed by the different letters are significantly different according to least significant difference test; $P \leq 0.05$ indicates significant difference. RHS = Royal Horticultural Society.

${ }^{\mathrm{y}}$ The pollen was cultured in B\&K medium containing $20 \%$ sucrose in a dark environment at $20{ }^{\circ} \mathrm{C}$ for $10 \mathrm{~h}$.

${ }^{x}$ Control: 'Dulce Rosa'.

${ }^{\text {w }}$ Abnormal floral organ in which the anthers within the involucre did not develop normally and no pollen was contained in the anther.

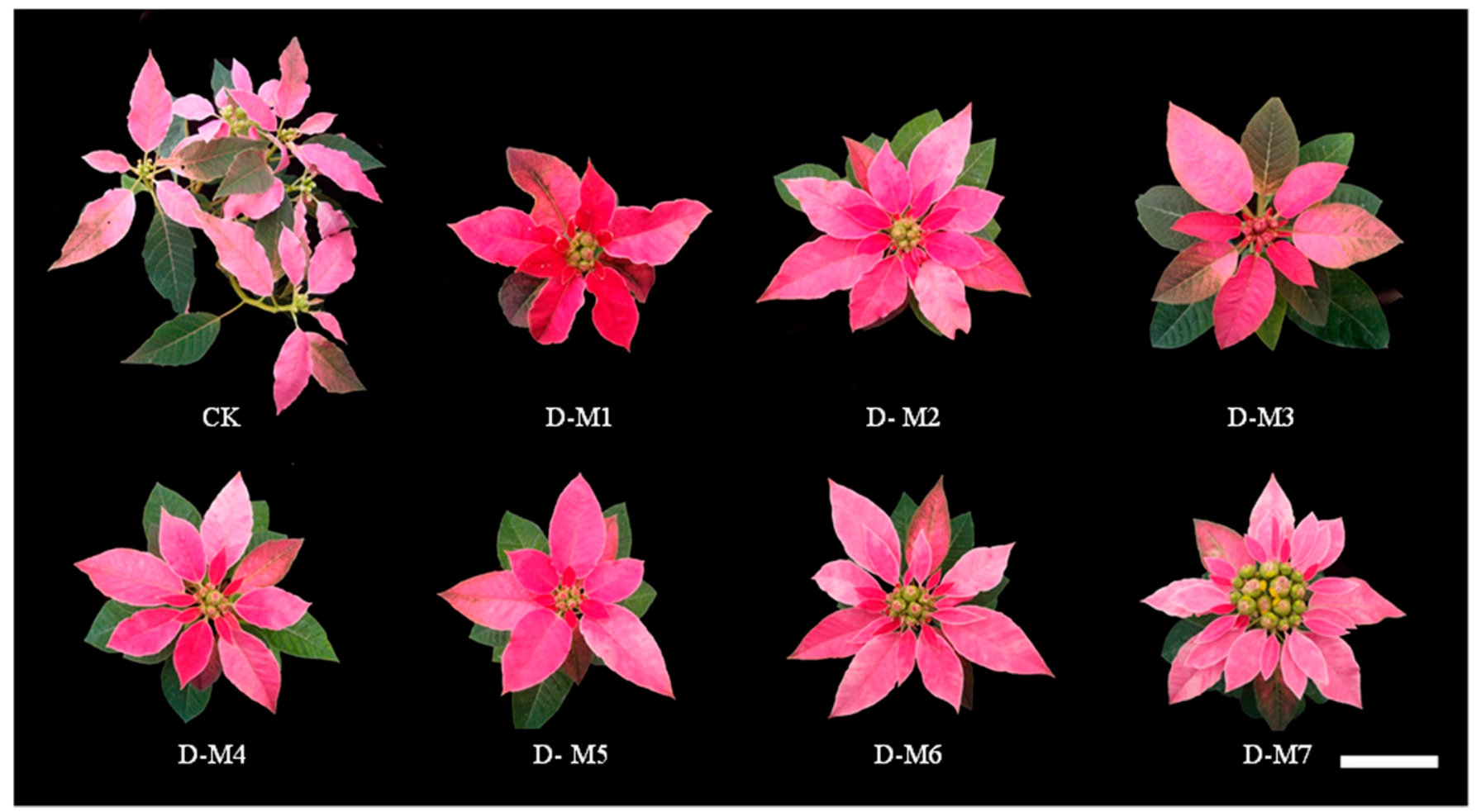

Fig. 1. Inflorescence of poinsettia 'Dulce Rosa' and its colchicine-induced mutants. Bar $=5 \mathrm{~cm}$. CK (control): 'Dulce Rosa', D-M1 to D-M7: mutant lines obtained by colchicine treatments.

highest pollen germination rate was obtained in P-M13 (27.5\%) (Table 4, Fig. 3I). Although P-M10 showed the same diploid level of DNA content as 'Princettia-Hot Pink', it showed high pollen germination rate $(22.5 \%)$, which was comparable to those of the tetraploid-level mutants. Some mutants (P-M1 and P-M11) with diploid level of DNA contents also showed pollen germination ability, although the germination rates were lower than $5 \%$. These non-tetraploid mutant strains with pollen germination ability had larger size of pollen diameter than 'Princettia-Hot Pink'. Moreover, most of the remaining mutants exhibited more or less different DNA contents compared with the donor plant 'Princettia-Hot Pink'. Especially, three mutant strains (P-M4, P-M9, P-M15) showed lower DNA contents than the original cultivar (Table 4).

\section{Discussion}

In a previous study, Pickens et al. (2006) tried colchicine in vitro treatment on poinsettia 'Winter Rose', in which several factors, such as colchicine concentration (0.00001, 0.0001, 0.001, and $0.01 \mathrm{mg} \cdot \mathrm{mL}^{-1}$ ), incubation duration $(0,1,2,4 \mathrm{~d})$, and different culture methods (liquid-solid and solid-solid medium) did not give any significant difference on the survival rate of the treated buds, and polyploidies could not be obtained. However, in the present study, polyploidies were successfully obtained by treating axillary buds with colchicine ex vitro. The results demonstrated that different application methods (cotton vs. lanoline) and colchicine concentrations affected the induction efficiency of polyploidy and bud survival rate. In 'Dulce Rosa', no correlation between the survival rate and treatment frequency was found between lanolin and cotton treatments used as a matrix (Table 1). In 'Princettia-Hot Pink', however, treatment frequency gave different effects on the survival of buds after colchicine treatment with lanolin and that with cotton; survival rates of the buds with lanolin were greatly reduced by twice treatment, whereas survival rates were increased by the $2-d$ 
treatment in the case of cotton (Table 2). The reasons for such complicated effects of treatment frequency and kind of matrix used for colchicine application are still unclear and need to be clarified.

Flow cytometric analysis revealed that colchicine treatments on 'Dulce Rosa' and 'Princettia-Hot Pink' induced many mutants with unexpected DNA contents apart from typical chromosome-doubled plants as described in results (Tables 3 and 4). These unexpected DNA content mutants are usually known to occur for the following reasons: failure of homologous pairing, nonseparation of chromosomes, a deferred anaphase, or the gain and loss of the entire chromosome strain of a cell. Because colchicine is an antimicrotubule agent, it interferes with the functioning of spindle fibers (Ranney, 2006). Therefore, it is reasonable to consider that the loss or addition of relatively few chromosomes had occurred in these mutants due to the impeded mitosis caused by colchicine treatment.

To solve the breeding problems caused by sterility, chromosome doubling technology has been successfully used to recover functional pollen in rose (Kermani et al., 2003) and carnation (Nimura et al., 2006). In
Table 4. Morphological traits of colchicine-induced mutants of poinsettia 'Princettia-Hot Pink' ${ }^{\mathrm{z}}$

\begin{tabular}{lcccccccc}
\hline Mutant & $\begin{array}{c}\text { Single } \\
\text { cyathium } \\
\text { diame }(\mathrm{cm})\end{array}$ & $\begin{array}{c}\text { Bract } \\
\text { length } \\
(\mathrm{cm})\end{array}$ & $\begin{array}{c}\text { Bract } \\
\text { width } \\
(\mathrm{cm})\end{array}$ & $\begin{array}{c}\text { Bract- } \\
\text { leaf } \\
\text { blade ratio }\end{array}$ & $\begin{array}{c}\text { Bract } \\
\text { color } \\
(\text { RHS })\end{array}$ & $\begin{array}{c}\text { Pollen } \\
\text { grain } \\
\text { diam }(\mu \mathrm{m})\end{array}$ & $\begin{array}{c}\text { Pollen } \\
\text { germination } \\
\text { rate }^{\mathrm{y}}(\%)\end{array}$ & $\begin{array}{c}\text { Relative } \\
\text { DNA }\end{array}$ \\
\hline Control $^{\mathrm{x}}$ & 11.3 & $4.9 \mathrm{j}$ & $2.8 \mathrm{~h}$ & $2.3 \mathrm{a}$ & $57 \mathrm{C}$ & $43.8 \mathrm{~d}$ & $0 \mathrm{~d}$ & 2.0 \\
P-M1 & 14.2 & $5.8 \mathrm{~h}$ & $3.6 \mathrm{ef}$ & $1.6 \mathrm{efg}$ & $67 \mathrm{C}$ & $51.7 \mathrm{~b}$ & $4.5 \mathrm{~d}$ & 2.03 \\
P-M2 & 14.2 & $5.6 \mathrm{i}$ & $2.8 \mathrm{~h}$ & $2.0 \mathrm{bc}$ & $67 \mathrm{C}$ & $-\mathrm{w}$ & - & 2.39 \\
P-M3 & 19.2 & $8.4 \mathrm{~b}$ & $4.7 \mathrm{ab}$ & $1.8 \mathrm{cde}$ & $67 \mathrm{C}$ & $51.9 \mathrm{~b}$ & $3.8 \mathrm{~d}$ & 2.50 \\
P-M4 & 19.7 & $8.5 \mathrm{ab}$ & $3.9 \mathrm{~d}$ & $2.2 \mathrm{ab}$ & $66 \mathrm{C}$ & $29.1 \mathrm{f}$ & $0.5 \mathrm{~d}$ & 1.36 \\
P-M5 & 16.0 & $5.6 \mathrm{hi}$ & $3.1 \mathrm{~g}$ & $1.7 \mathrm{defg}$ & $57 \mathrm{~B}$ & - & - & 2.0 \\
P-M6 & 12.9 & $6.7 \mathrm{f}$ & $3.4 \mathrm{f}$ & $1.8 \mathrm{cde}$ & $63 \mathrm{~B}$ & - & - & 4.72 \\
P-M7 & 15.7 & $7.1 \mathrm{e}$ & $3.7 \mathrm{de}$ & $2.3 \mathrm{a}$ & $57 \mathrm{C}$ & - & - & 2.0 \\
P-M8 & 14.2 & $5.5 \mathrm{hi}$ & $3.5 \mathrm{ef}$ & $1.6 \mathrm{fg}$ & $61 \mathrm{C}$ & $52.7 \mathrm{~b}$ & $13.0 \mathrm{c}$ & 4.54 \\
P-M9 & 19.7 & $8.7 \mathrm{a}$ & $4.9 \mathrm{a}$ & $1.8 \mathrm{def}$ & $67 \mathrm{C}$ & $47.1 \mathrm{c}$ & $4.0 \mathrm{~d}$ & 1.68 \\
P-M10 & 19.7 & $7.8 \mathrm{~d}$ & $5.0 \mathrm{a}$ & $1.6 \mathrm{efg}$ & $57 \mathrm{~B}$ & $56.7 \mathrm{a}$ & $22.5 \mathrm{ab}$ & 2.0 \\
P-M11 & 18.6 & $8.1 \mathrm{c}$ & $3.7 \mathrm{def}$ & $2.2 \mathrm{ab}$ & $67 \mathrm{C}$ & $39.0 \mathrm{e}$ & $0.8 \mathrm{~d}$ & 2.0 \\
P-M12 & 14.3 & $6.2 \mathrm{~g}$ & $4.2 \mathrm{c}$ & $1.5 \mathrm{~g}$ & $57 \mathrm{C}$ & $51.5 \mathrm{~b}$ & $2.5 \mathrm{~d}$ & 2.72 \\
P-M13 & 17.8 & $8.1 \mathrm{c}$ & $4.9 \mathrm{a}$ & $1.7 \mathrm{def}$ & $57 \mathrm{~B}$ & $52.8 \mathrm{~b}$ & $27.5 \mathrm{a}$ & 3.75 \\
P-M14 & 15.7 & $7.3 \mathrm{e}$ & $4.5 \mathrm{~b}$ & $1.7 \mathrm{def}$ & $57 \mathrm{C}$ & $56.0 \mathrm{a}$ & $17.8 \mathrm{bc}$ & 4.72 \\
P-M15 & 11.2 & $4.9 \mathrm{j}$ & $2.6 \mathrm{~h}$ & $1.9 \mathrm{~cd}$ & $57 \mathrm{C}$ & - & - & 1.48 \\
\hline
\end{tabular}

${ }^{\mathrm{z}}$ Means within a column followed by the different letters are significantly different according to least significant difference test; $P \leq 0.05$ indicates significant difference.

${ }^{\mathrm{y}}$ The pollen was cultured in B\&K medium containing $20 \%$ sucrose in a dark environment at $20{ }^{\circ} \mathrm{C} \mathrm{for} 10 \mathrm{~h}$. 'Control: 'Princettia-Hot Pink'.

${ }^{\mathrm{w}}$ Abnormal floral organ in which the anthers within the involucre did not develop normally and broke to release the pollen. the present study, 11 mutants obtained after colchicine treatments showed normal floral organs with some fertile pollen as assessed by pollen germination ability ( 1 for 'Dulce Rosa' and 10 for 'Princettia-Hot Pink') (Tables 3 and 4). The stamens of the original 'Dulce Rosa' did not protrude from the involucre. However, some of the mutants developed normal stamens that could release pollen. In mutants D-M1 and P-M13, pollen grain revealed to have regular shape and larger size compared with those of 'Dulce Rosa' and 'Princettia-Hot Pink', respectively (Tables 3 and 4, Fig. 3C and $\mathrm{H}$ ). The same results were also observed in polyploidy mutant of verbena (Lucía et al., 2015).

In the present study, the polyploidy mutants of 'Dulce Rosa' and 'Princettia-Hot Pink' obtained through colchicine treatment had significantly different traits, such as greater bract length and width and darker bract colors than donor plants (Tables 3 and 4, Figs. 1 and 2). Trait variations such as altered color and shape of flowers and greater leaf areas have previously been shown in other crops. For example, polyploidies of Hebe 'Oratia Beauty' had greater stalk diameter (Gallone et al., 2014) and crape myrtle (Lagerstroemia indica) tetraploid mutants exhibited broader and rounder leaves, larger petals, and larger inflorescence diameter; the size of their capsules was nearly twice that of the diploids (Ye et al., 2010). Polyploidy mutants of verbena (Glandularia) exhibited rounder and thicker leaves and petals with darker petal colors compared with the original plant (Lucía et al., 2015). Trait variations in the aforementioned polyploidy mutants and our colchicine-induced mutants are likely related to chromosome quantity increases, which may lead to repetitive

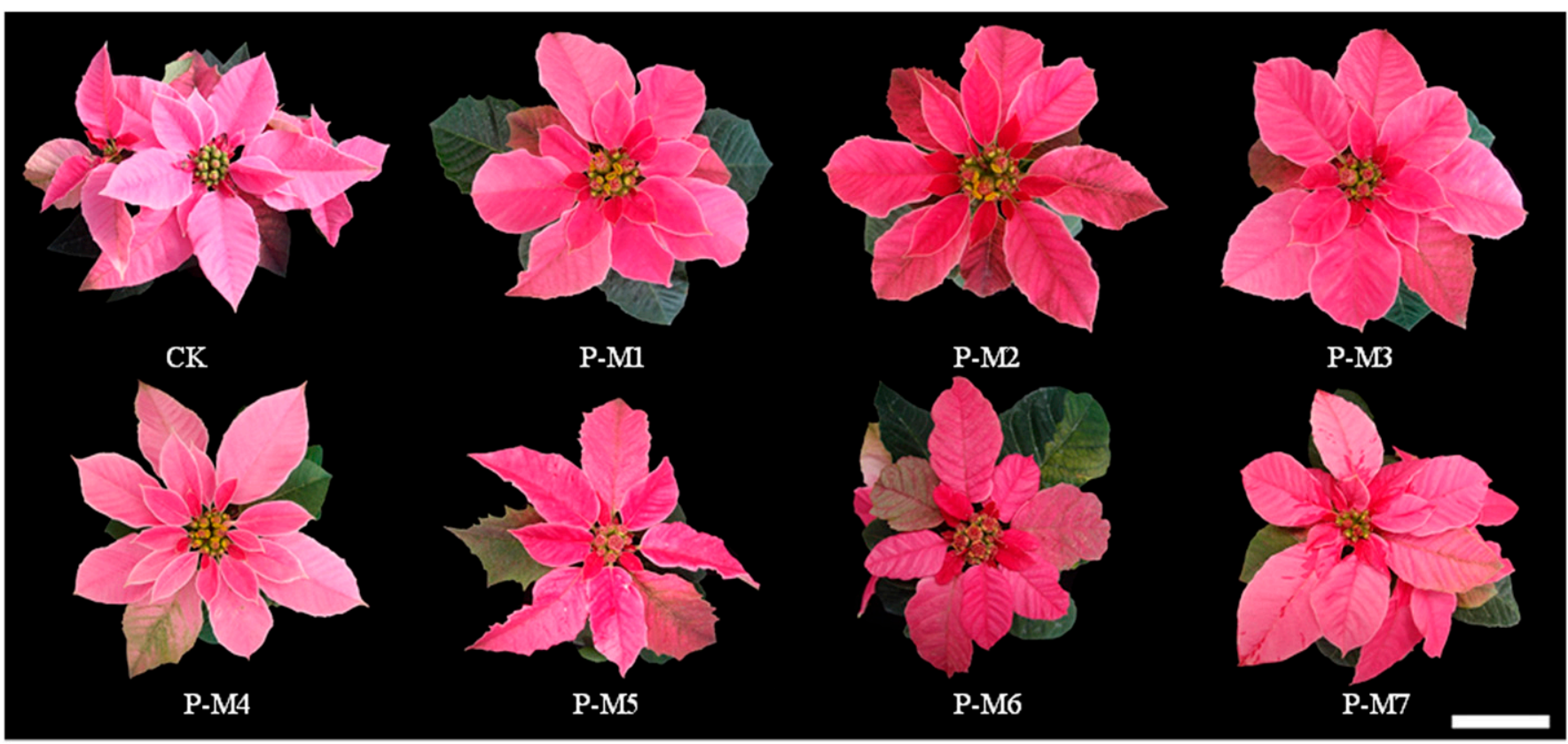

Fig. 2. Inflorescence of poinsettia 'Princettia-Hot Pink' and its colchicine-induced mutants. Bar $=5 \mathrm{~cm}$. CK (control): 'Princettia-Hot Pink', P-M1 to P-M7: mutant lines obtained by colchicine treatments. 

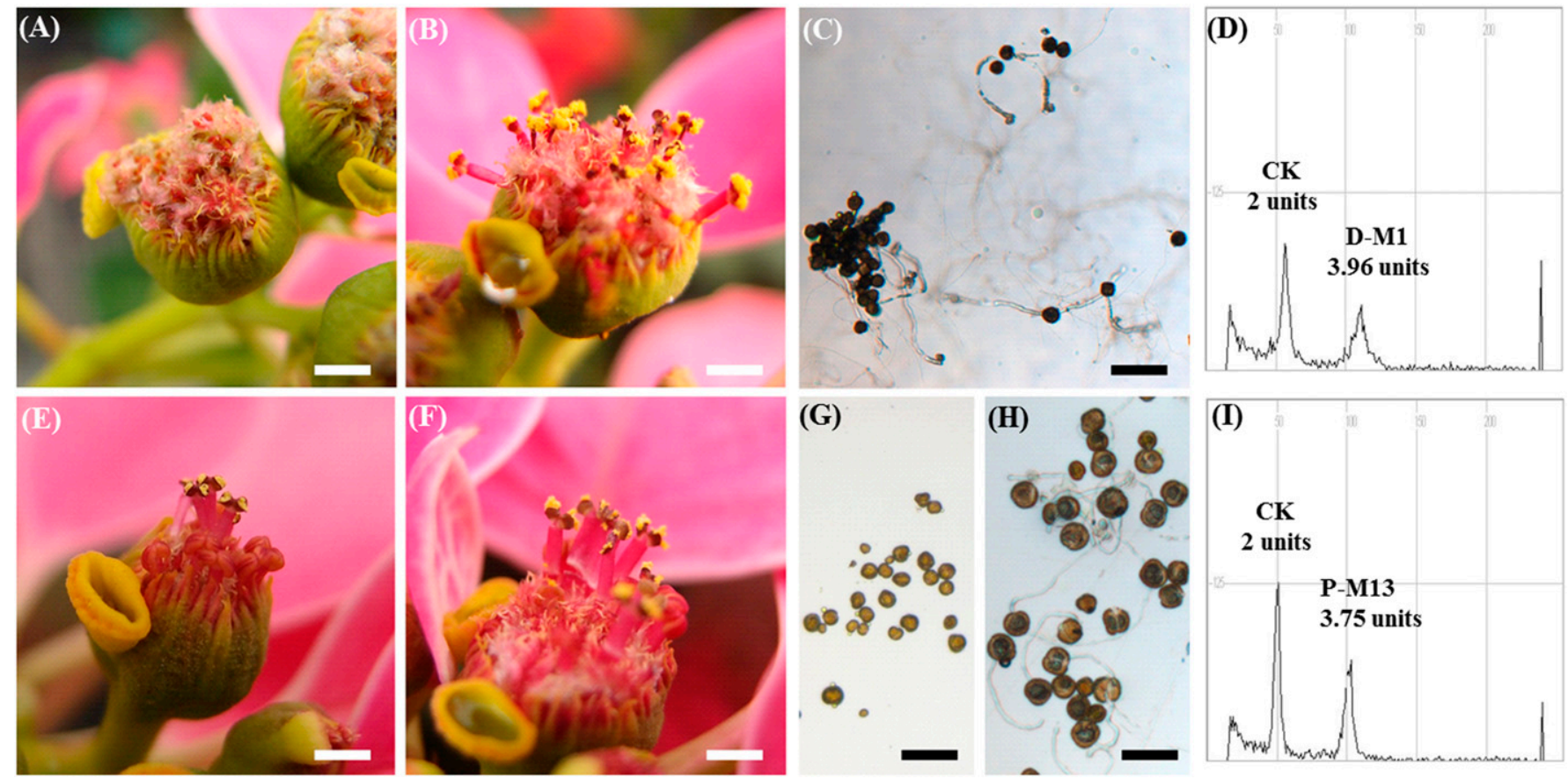

Fig. 3. The inflorescence and pollen character and relative DNA content on poinsettias, 'Dulce Rosa', 'Princettia-Hot Pink', and their individual mutants. (A) Abnormal involucre of 'Dulce Rosa'. (B) Dehisced anther of 'Dulce Rosa' mutant D-M1. (C) Pollen germination of 'Dulce Rosa' mutant D-M1. (D) The relative DNA contents of CK (control): 'Dulce Rosa' and mutant D-M1. (E) The involucre of 'Princettia-Hot Pink'. (F) Anther dehisced 'Princettia-Hot Pink' mutant P-M13. (G) Non-pollen germination of 'Princettia-Hot Pink'. (H) Pollen tube elongation of 'Princettia-Hot Pink' mutant P-M13. (I) The relative DNA contents of CK (control): 'Princettia-Hot Pink' and mutant P-M13. Bar $(\mathbf{A}, \mathbf{B}, \mathbf{E}, \mathbf{F})=0.5 \mathrm{~cm} ;(\mathbf{C}, \mathbf{G})=200 \mu \mathrm{m} ;(\mathbf{H})=100 \mu \mathrm{m}$.

expression of the quantitative traits and finally to trait differences (Chen, 2007).

\section{Conclusion}

In summary, two interspecific hybrid cultivars of poinsettia 'Dulce Rosa' and 'Princettia-Hot Pink' were able to create polyploidy mutants by colchicine treatments. The polyploidies showed restored pollen germination ability to some extent, and the mutants with various plant characteristics and valuable traits, such as specific bract type and larger bract size, also were obtained. This information might be useful for the poinsettia breeders to obtain the amphidiploid mutant with functional pollen for continuing their breeding works, as well as to use nonpolyploidy mutants with ornamental value directly or as novel germplasm.

\section{Literature Cited}

Brewbaker, J.L. and B.H. Kwack. 1963. The essential role of calcium ion in pollen germination and pollen tube growth. Amer. J. Bot. 50:859-865.

Chen, Z.J. 2007. Genetic and epigenetic mechanisms for gene expression and phenotypic variation in plant polyploids. Annu. Rev. Plant Biol. 58:377-406.

Chen, Y.M. and M. Mii. 2012a. Interspecific hybridization of Begonia semperflorens (section Begonia) with B. pearcei (section Eupetalum) for introducing yellow flower color. Plant Biotechnol. 29:77-85.

Chen, Y.M. and M. Mii. 2012b. Inter-sectional hybrids obtained from reciprocal crosses between Begonia semperflorens (section Begonia) and $B$. 'Orange Rubra' (section Gaerdita $\times$ section Pritzelia). Breed. Sci. 62:113-123.

Datta, S.K. 1991. Role of mutation breeding in floriculture. Plant Mutation Breeding for Crop Improvement, IAEA /FAO I. Symp. Proc., Vienna, 18-22 June 1990.

Ecke, P., Jr., O.A. Matkin, and D.E. Hartley. 1990. The poinsettia manual. 3rd ed. Paul Ecke Poinsettias. Encinitas, CA.

Ecke, P., III, J.E. Faust, A. Higgins, and J. Williams. 2004. The Ecke poinsettia manual. Ball Publishing, Batavia, IL.

Gallone, A., A. Hunter, and G.C. Douglas. 2014. Polyploid induction in vitro using colchicine and oryzalin on Hebe 'Oratia Beauty': Production and characterization of the vegetative traits. Scientia Hort. 179:59-66.

Kermani, M.J., V. Sarasan, A.V. Roberts, K. Yokoya, J. Wentworth, and V.K. Sieber.
2003. Oryzalin-induced chromosome doubling in Rosa and its effects on plant morphology and pollen viability. Theor. Appl. Genet. 107:1195-1200.

Lucía, G.R., I. Jesica, C. Andrea, B. Verónica, B. Paula, P.Á. Sandra, and E. Alejandro. 2015. A protocol for the in vitro propagation and polyploidization of an interspecific hybrid of Glandularia $(G$. peruviana $\times$ G. scrobiculata). Scientia Hort. 184:46-54.

Nimura, M., J. Kato, H. Horaguchi, M. Mii, K. Sakai, and T. Katoh. 2006. Induction of fertile amphidiploids by artificial chromosome-doubling in interspecific hybrid between Dianthus caryophyllus L. and D. japonicas Thunb. Breed. Sci. 56:303-310.

Pickens, K.A., Z.M. Cheng, and S.A. Kania. 2006. Effect of colchicine and oryzalin on callus and adventitious shoot formation of Euphorbia pulchurrima 'Winter Rose'. HortScience 41:1651-1655.

Ranney, T.G. 2006. Polyploidy: From evolution to new plant development. Proc. Intl. Plant Propagator Soc. 56:137-142.

Ye, Y.M., J. Tong, X.P. Shi, W. Yuan, and G.R. Li. 2010. Morphological and cytological studies of diploid and colchicine-induced tetraploid lines of crape myrtle (Lagerstroemia indica L.). Scientia Hort. 124:95-101. 